\title{
Sacrococcygeal teratoma: Clinical characteristics and long-term outcome in Nigerian children
}

\author{
Lohfa B. Chirdan, Aba F. Uba, Sunday D. Pam ${ }^{1}$, Stephen T. Edino ${ }^{4}$, Barnabas M. Mandong ${ }^{2}$, \\ Oluwabunmi 0. Chirdan ${ }^{3}$ \\ Paediatric Surgery Unit, Department of Surgery, ${ }^{1}$ Special Baby Care Units, Departments of Paediatrics, \\ ${ }^{2}$ Pathology, ${ }^{3}$ Community Medicine, J os University Teaching Hospital, J os, Nigeria ${ }^{4}$ Surgery, Aminu Kano Teaching \\ Hospital, Kano, Nigeria
}

Correspondence to: Dr. Lohfa B Chirdan, Paediatric Surgery Unit, Department of Surgery, J os University Teaching Hospital, PMB 2076, Jos, Nigeria. E-mail: lohfab@ yahoo.com

\begin{abstract}
Background/Purpose: The excision of sacrococcygeal teratoma (SCT) may be associated with significant long-term morbidity for the child. We reviewed our experience with SCT in a tertiary health care facility in a developing country with particular interest on the long-term sequelae.

Methods: Between January 1990 and May 2008 inclusive, 38 consecutive children with the diagnosis of SCT were identified from the operation register and the Cancer Registry of the Jos University Teaching Hospital. Their clinical presentation, investigation, operative findings, histology report, and outcome were recorded and analyzed. The long-term follow-up of some of the patients were also recorded and analyzed.

Results: There were 31 females and 7 males. Twenty-three patients presented during the neonatal period with a median age at presentation of 7 days (range 1-18 days) and a median weight at presentation of $2.8 \mathrm{~kg}$ (range $2.0-3.6 \mathrm{~kg}$ ), 10 presented between 1 month and 12 months, while 5 were older than 1 year at presentation. Most of the patients had significantly external tumors. Excision of the tumor was mainly by the sacral route, four had abdominal-sacral excision. Histology was mainly benign; four were malignant at presentation. Four children with malignant disease had chemotherapy in addition to excision of the tumor. Eight had immediate post-operative wound-related complications while three children died, two of the deaths were related to anesthesia, while one died of colostomy complications. Twenty-one (60\%) were followed up for a median duration of 6 years (range 1 month- 8 years). Two (9.5\%) had recurrent disease after primary excision; five $(23.8 \%)$ had some degree of functional impairment at the follow-up. Conclusion: While SCT is usually benign, recurrence, malignant transformations in patients who present late and longterm functional sequelae are problems that must be tackled by the care givers. A multi-center study may be necessary to characterize this disease in developing countries and assess the long-term functional sequelae in survivors.
\end{abstract}

Keywords: Clinical characteristics, long-term functional sequelae, sacrococcygeal teratoma

\section{Résumé}

Arrière-plan/objectif: L'excision. de teratoma (SCT) sacrococcygeal peut être associé importantes à long terme morbidité pour l'enfant. Nous avons revu notre expérience de SCT dans un tertiaire facilité de soins de santé dans un pays en développement avec un intérêt particulier sur la séquelles à long terme.

méthodes: entre Janvier 1990 et mai 2008 inclusivement, 38 enfants consécutifs avec le diagnostic du SCT ont été identifié à partir du Registre d'opération et le Registre du cancer de le Jos Teaching CHUV. Leur présentation clinique, enquête, résultats opérationnels, rapport de l'histologie et issue étaient enregistrées. et analysées. Le suivi à long terme de certains des patients ont également été enregistrées et analysées.

Résultats: II Y avait les 31 femelles et les 7 hommes. Vingt trois présentées lors de la période néonatale avec une médiane âge à la présentation de 7 jours (plage 1-18 jours) et un poids médian à Présentation de 2,8 kg (gamme 2.0-3,6 kg), 10 présentés entre 1 mois et douze mois alors que 5 ont été plus de 1 an à la présentation. Plupart des patients avaient considérablement externes de tumeurs. L'excision de la tumeur était principalement par sacrée itinéraire, quatre avaient exision abdominale sacrée. Histologie était principalement bénigne; 4 ont été malin à la 
présentation. Quatre enfants atteints de maladies malignes avait chimiothérapie en plus de l'excision de la tumeur. Huit avaient immédiate post-operative wound complications connexes alors que 3 enfants morts, 2 des décès ont été liés à l'anesthésie tandis que 1 mortes de complications colostomie. Vingt et un (60\%) ont été suivies pour une durée moyenne de 6 ans (plage de 1 mois - 8 ans).Deux (9,5\%) avait maladie récurrente après excision primaire; 5 $(23,8 \%)$ avaient certains degré de déficience fonctionnelle au suivi.

Conclusion: Bien que SCT est habituellement bénigne, périodicité, transformations malignes chez les patients qui présentent tardive et séquelles fonctionnelles à long terme sont des problèmes qui doivent être abordés par les soins donneurs. Étude multicentrique peut être nécessaire de qualifier cette maladie dans les pays en développement et d'évaluer les séquelles fonctionnels à long terme de survivants.

Mots cles: Sacrococcygeal Tératome, les caractéristiques cliniques, les séquelles fonctionnelles à long terme

DOI: $10.4103 / 1596-3519.56238$

PMID: 19805941

\section{Introduction}

Sacrococcygeal teratoma (SCT) is a common germ cell tumor of childhood affecting between 1:40,000 and 1:35 000 live births. ${ }^{[1,2]}$ Most patients present during the neonatal period with a sacral mass, though some intrapelvic tumors may present later. The diagnoses of SCT are being increasingly made within the late second and third trimesters with the advent of improved antenatal imaging techniques, and planned Caesarian delivery is being offered to some pregnant women with better outcome. ${ }^{[3,4]}$ Previous reports from Nigeria had focused mainly on the clinical presentation without details on the long-term outcome. ${ }^{[5,6]}$ Besides reports on the long-term follow-up of children treated for SCT worldwide is scanty. The aim of this present article was to review the outcome of SCT in a tertiary healthcare institution in Central Nigeria with particular interest on the long-term outcome.

\section{Materials and Methods}

The operation registrar and the Cancer Registry of the Jos University Teaching Hospital were accessed to identify all children treated for SCT at the Jos University Teaching Hospital, Jos, Nigeria, between January 1990 and May 2008 inclusive. The demographic data, clinical presentation, investigations, and histopathology reports of the patients were recorded from case notes, operation notes, and discharge summary sheets. The surgical management with respect to resection of the primary tumor and the early and late complications were also recorded. Our usual operative approach for excision of this tumor is to make a chevron incision, after a piece of gauze impregnated with paraffin has been inserted into the rectum to make its recognition easier. We then transact the lower sacrum and control the middle sacral artery early in the operation to avoid unnecessary hemorrhage. The tumor is then dissected out enbloc from the rectum that has been made easily visible with the gauze in the rectum, the pelvic diaphragm, and the gluteal muscles. The tumor including the coccyx is then removed. In patients with significant intra-pelvic extensions of the tumor, we use an abdomino-sacral route for the total excision of the tumor. Patients with intestinal obstruction and or bladder outlet obstruction usually would have colostomy constructed. For malignant tumors, we use neoadjuvant chemotherapy before excision of the tumors. Outcomes relating to survival, tumor recurrence, bowel and urinary functions were analyzed from the long-term clinical follow-up of some of the patients whose data were available.

\section{Results}

\section{Presentation}

Forty-one children were suspected to have SCT over the study period; three were excluded (one had sacral meningocele, one had fibrolipoma, while the parents of one child refused surgery) leaving 38 with histologically confirmed SCT and form the basis of this report. There were $31(81.6 \%)$ females and $7(18.4 \%)$ males. Twelve pregnancies were supervised and had delivery in a health care facility. Four (10.5) had antenatal diagnosis using USS; two of them had Caesarian delivery at our hospital due to dystocia. The remaining 26 had their deliveries at home under supervision of traditional birth attendants (TBAs). There was no history of tumor rupture or hemorrhage. Twenty-three (60.5\%) presented during the neonatal period; their ages at presentation ranged from 1 to 18 days (median 7 days). Their weight at presentation ranged from $2.0 \mathrm{~kg}$ to $3.6 \mathrm{~kg}$ (median $2.8 \mathrm{~kg}$ ). Fifteen $(39.5 \%)$ presented outside the neonatal period; 10 presented between 2 and 11 months (median 5 months), while 5 presented between 1.5 and 6 years of age (median 3.5 years). One child was premature and had associated congenital heart disease, while one other child had associated anal stenosis. 
Clinical assessment included a detailed history and physical examination, including a digital rectal examination in all. Imaging studies included lateral sacral radiographs and additional chest radiographs in four. None had a CT scan, as this investigation was unavailable during the study period. One child presented with urinary obstruction and had a micturating cystourethrogram as part of her assessment. Pre-operatively all had estimation of the hematocrit, serum urea, and electrolytes. Alpha fetoprotein estimation was done in 30 children at presentation and 17 at the follow-up. Clinically, there were 17 Altmann type I [Figure 1]; 15 type II; 4 type III; and 2 type IV tumors.

\section{Surgical management}

Excision of the tumor was done in all the patients. Thirty-four (89.5\%) had complete tumor excision via the sacral route only. Four (11.8\%) had combine abdomino-sacral resection of tumor. Two children with large intra-abdominal extension of SCT had preliminary colostomy; in one, excision through the abdomino-sacral route was done, while the other child with intestinal obstruction and whose tumor was malignant with fungating ulcers [Figure 2]

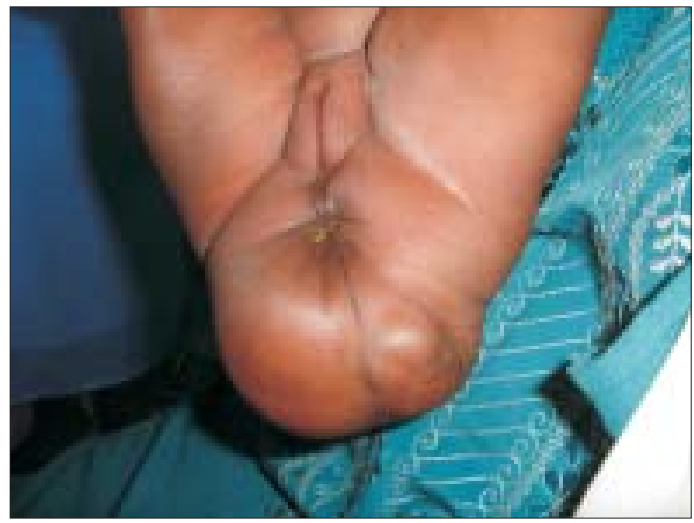

Figure 1: Typical presentation of neonates with sacrococygeal teratoma

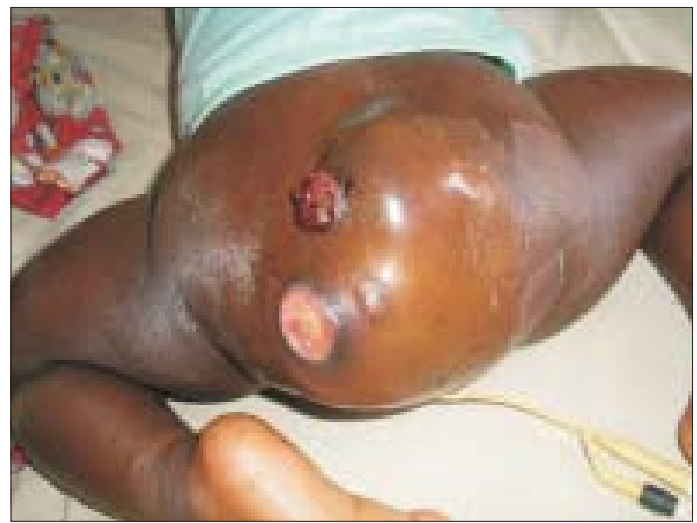

Figure 2: One of three children who presented with malignant teratoma had a preliminary divided sigmoid colostomy and cytotoxic chemotherapy. This considerably reduced the tumor and a sacral excision was possible. She had her colostomy closed 2 weeks after and had completed her course of cytotoxics. She has no recurrence 2 years after excision and chemotherapy. Two other children had colostomy after resection for iatrogenic rectal injury during excision and postoperative wound dehiscence, respectively.

\section{Pathology}

The tumor was cystic in 8 children (all neonates); cystic with solid areas in 20 (15 neonates, 5 infants) and solid in 10. The primary histology showed mature teratoma in 23 (16 neonates and 7 older children) and immature teratoma in 9 (5 neonates and 4 older children). In four, the histology was reported as malignant teratoma (MT), while the histology of two was reported as endodermal sinus tumor (EST) [Table 1].

\section{Complications and long-term follow-up}

Immediate postoperative complications occurred in eight $(21.1 \%)$ children. Complete wound dehiscence occurred in three, one had a colostomy constructed and the remaining two were successfully managed without colostomy. Five had partial wound dehiscence that healed with local wound care. One had intra-operative rectal injury, and a colostomy was constructed at operation. There were three (7.9\%) deaths. One died on table shortly after induction of anesthesia; the other died a few hours after surgery, while the third child died of colostomy complications. Of the 35 survivors, 14 were lost to follow-up, while $21(60 \%)$ were followed up up for a median duration of 6 years (range 1 month-8 years). Of these, two with initial histology of mature teratoma had recurrent disease 24 and 36 months after primary excision requiring re-excision, and were disease-free at 1 year of re-excision. Of the four children who had malignant teratoma at presentation, two were lost to follow-up, one had chemotherapy and re-excision, while one was free of tumor at 2 years of follow-up. Two children who had

\begin{tabular}{lcccc}
\hline \multicolumn{3}{l}{ Table 1: Tumor histology } \\
\hline Histology & Neonates & $\begin{array}{c}>28 \\
\text { days } \\
<12 \\
\text { months }\end{array}$ & $\begin{array}{c}>12 \\
\text { months }\end{array}$ & Total \\
\hline $\begin{array}{l}\text { Mature } \\
\text { teratoma }\end{array}$ & 16 & 6 & 1 & 23 \\
$\begin{array}{l}\text { Immature } \\
\text { teratoma }\end{array}$ & 5 & 3 & 1 & 9 \\
$\begin{array}{l}\text { Malignant } \\
\text { teratoma }\end{array}$ & - & 1 & 3 & 4 \\
$\begin{array}{l}\text { EST } \\
\text { Total }\end{array}$ & 2 & - & - & 2 \\
\hline EST: Endodermal sinus tumor & 10 & 5 & 38 \\
\hline
\end{tabular}

Page | 107 
excision during the neonatal period had patulous anus with fecal soiling; two other children had nocturnal enuresis at 6 and 8 years of age. One child had urinary incontinence with recurrent urinary tract infection. The details of the children with long-term complications are summarized in Table 2.

\section{Discussion}

This 13-year review revealed a number of characteristics of this disease from sub-Saharan Africa. A female preponderance noted in this report agrees with most other reports from other parts of the world except in one report from India where there was equal sex distribution. ${ }^{[4,6-8]}$ Patients with sacrococcygeal teratomas generally present in two clinical patterns; those presenting during the neonatal period with predorminantly benign tumors and those presenting after the neonatal period, usually as older infants and children with primarily intrapelvic tumors with a likely malignant histology. ${ }^{[7]}$ More than $50 \%$ of the children in this report presented during the neonatal period with predorminantly extrapelvic tumors. In developed countries, many more cases are diagnosed antenatally and therefore antenatal intervention and or planned Caesarian delivery is done for large tumors to avoid dystocia, tumor rupture, hemorrhage, or death. ${ }^{[3,4,9]}$ The situation is different in our setting where many pregnant women have no access to obstetric care; thereby many of the deliveries are by Traditional Birth Attendants (TBAs). However, as health care becomes available to more people from developing countries, and with increasing availability of antenatal imaging techniques and screening, more of our patients may be diagnosed antenatally. This would mean that more of them may have planned caesarian deliveries and better outcome. Over half of our patients presented during the neonatal period. This may be due to the fact that most of the tumors were external. However, it is pertinent to note that in many societies in Africa, such children are considered monsters and therefore may not have the opportunity of getting to the hospitals and left to die at home. It is also interesting to note that a good number $(41.6 \%)$ of our patients present outside the neonatal period and about four $(11.1 \%)$ presented after 1 year of age. In developing countries, poverty and inaccessibility to tertiary health care facilities may play some role on the time of presentation of patients to the hospital. Besides, some of the patients with predorminantly intrapelvic tumors may present with urinary or bowel obstruction as in one of our patients. All our patients who presented after 1 year of age had malignant diseases at presentation. The high rate of malignancy with late presentation had been noted by other reports. ${ }^{[10-14]}$ In this present report, the four children with malignant disease at presentation presented outside the neonatal period.

Associated congenital anomalies are common in children with sacrococcygeal teratoma. These associated anomalies include anorectal anomalies, spinal dysraphism, and limb abnormalies. Ascraft and Holder in 1965 reported two children with presacral tumor and anal stenosis and later 17 others with presacral tumor and sacral defects with most of them having anal stenosis in six kindreds. [15,16] This led them to suggest an autosomal dominant nature of the tumor. Currarino later described three more cases and suggested that the etiology may be related to adhesions between the ectoderm and neural endoderm causing a split notochord ${ }^{[17]}$ In another report from North-Eastern Nigeria, associated congenital anomalies were noted in three of the patients. ${ }^{[6]}$ In this present report, two children had associated congenital anomalies: one child with congenital heart disease and the other child with anal stenosis with tethering of the cord. It may appear that associated congenital anomalies are not common in children presenting in our environment. This may be related to the fact that most of the children with associated life-threatening anomalies would have died at home without being taken to the hospital.

The post-operative morbidity noted in $21 \%$ was mainly wound infection that could be because of fecal soilage of the wound. This could be avoided by the construction of a colostomy at the time of

\begin{tabular}{|c|c|c|c|c|}
\hline Sex & Age last clinic visit & Age at operation & Altmann type & Bowel/bladder \\
\hline $\mathrm{F}$ & 4 years & 10 months & III & $\begin{array}{l}\text { Urinary incontinence } \\
\text { Recurrent UTI }\end{array}$ \\
\hline $\mathrm{F}$ & 6 years & 3 years & I & Nocturnal enuresis \\
\hline M & 8 years & 2 years & II & Nocturnal enuresis \\
\hline $\mathrm{F}$ & 4 years & 14 days & ॥ & Patulous anus + soiling \\
\hline $\mathrm{F}$ & 32 years & 3 months & II & $\begin{array}{l}\text { Patulous anus, soiling } \\
\text { Perineal anesthesia }\end{array}$ \\
\hline F2 & $1 / 2$ years & 18 days & II & Recurrence \\
\hline $\mathrm{F}$ & 2 years & 7 days & 1 & Recurrence \\
\hline
\end{tabular}


surgery; however, colostomy may be associated with its own morbidity and additional cost and re-operation for closure. Wound contamination can also be avoided by the judicious placement of the skin incision and regular anal cleansing by the mothers. For patients in whom we anticipate poor anal hygiene, we usually leave a syringe in the anus for 3 days to divert feces from the wound, and since the introduction of this procedure, the incidence of wound dehiscence has greatly reduced.

The overall mortality in this report was $3 / 36$ (8.3\%); two of the deaths were directly related to anesthesia. In developing countries, anesthetic complications are common due to unavailability of trained anesthesiologists. The risk increases when operating on neonates and in neonates with SCT who have huge tumors with an increased risk of cardiac arrest after removal. In our center, we still use the services of nurse anesthesiologists due to unavailability of trained physician anesthesiologists. Recurrence after excision of benign or immature SCT has been documented and is common after the excision of malignant disease. ${ }^{[11]}$ Two of our patients with an initial benign histology had recurrence. Four of our patients had malignant histology on presentation; two were lost to follow-up after initial excision and chemotherapy, while two were well at 12 and 24 months after surgical excision and chemotherapy. Even though our patients with malignant disease were few, it would appear that they do well after chemotherapy and excision as noted by Wakhlu et al. ${ }^{[8]}$

A number of reports have attempted to assess longterm outcome after treatment of SCT; $;^{[8,10,11,15-17]}$ which include continence, quality of life, and sexual function. In one UK study on the long-term followup of children treated for SCT, ${ }^{[18]}$ a third had some functional problems, and Malone et al, found as many as $41 \%$ of children treated for SCT with some long-term functional sequelae. ${ }^{[16]}$ In this present series, only $21(60 \%)$ had some long-term follow-up information; 5 (23.8\%) of them had some degree of functional impairments [Table 1].

In developing countries, we may not know the exact prevalence of our patients with long-term sequelae after excision of SCT, as many of them may not come back after initial excision of the tumor. However, with improved health care delivery in the developing world due to improved economy and advocacy, many of the children with SCT would have access to healthcare and so many would survive and reach adulthood. It means then that the problem of long-term function must be on the minds of care givers as they manage this group of patients. Besides, clinicians and counselors need to explain to the parents of these children that excision of a benign tumor may be accompanied by significant long-term functional sequelae for their child. A multi-center study of those few who come back for follow-up in the various care centers may be necessary to quantify the magnitude of these problems in developing countries.

\section{References}

Page | 109

1. Pantoga E, Llobet R, Gonzales-Flores B. Retroperitoneal teratoma: Historical review. J Urol 1996;115:520-3.

2. Laberge JM, Nguyen LT, Shaw KS. Teratomas, dermoids and other soft tissue tumours. In: Ascraft KW, editor. Pediatric surgery, $3^{\text {rd }}$ ed. Philadelphia: Saunders; 2000. p. 905-26.

3. Graf JL, Albanese CT. Fetal sacrococcygeal teratoma. World J Surg 2003;27:84-6.

4. Flake AW. Fetal sacrococcygeal teratoma. Semin Pediatr Surg 1993;2:113-20.

5. Nmadu PT. Sacrococcygeal teratoma in Zaria, Nigeria: Report of 47 cases. Ann Trop Paediatr 1995;15:299-302.

6. Abubakar AM, Nggada HA, Chinda JY. Sacrococcygeal teratoma in northeastern Nigeria: 18 year experience. Pediatr Surg Int 2005 21:645-8.

7. Billmore DF, Grosfeld JL. Teratomas in childhood: Analysis of 142 cases. J Pediatr Surg 1986;21:548-51.

8. Wakhlu A, Misra S, Tandon AK, Wakhlu AK. Sacrococcygeal teratoma. Pediatr Surg Int 2002;18:384-7.

9. Antaby EY, Yagel S. Route of delivery of fetuses with structural anomalies. Eur J Obstet Gynecol Reprod Biol 2003;106:5-9.

10. Gabra HO, Jesudason EC, Mcdowel HC, Pizer BL, Losty PD. Sacrococcygeal teratoma- a 25-year experience in a UK regional centre. J Pediatr Surg 2006;41:1513-6.

11. Rescola FJ, Sawin RS, Coran AG, Dillon PW, Azizkhan RG Long term outcome for infants and children with sacrococcygeal teratoma: A Report from the Children's cancer group. J Pediatr Surg 1998;33:171-6.

12. Atmann RP, Randolph JG, Lilly JR. Sacrococcygeal teratoma: American Academy of Pediatrics Surgical Section Survey-1973. J Pediatr Surg 1974;9:389-98.

13. Grosfeld JL, Ballantine TV, Lowe D, et al Benign and malignant teratoma in children: Analysis of 85 children. Surgery 1976;80:297-305.

14. Hickey RC, Layton JM. Sacrococcygeal teratoma. Cancer 1954;7:1031-43.

15. Havranek $P$, Hedlund $H$, Reubenson A, Guth D, Husberg $M$, Frykberg $T$, et al. Sacrococcygeal teratoma in Sweden between 1978 and 1989: Long term functional results. J Pediatr Surg 1992;27:916-8.

16. Malone PS, Spitz L, Kiely EM, Brereton RJ, Duffy PG, Ransley PG. The functional sequelae of sacrococcygeal teratoma. J Pediatr Surg 1990;25:679-80.

17. Schmidt B, Herlik A, Uray E, Ratschek M, Lackner H, Hollwarth ME. Sacrococcygeal teratoma: Clinical course and prognosis with a special view to long term functional results. Pediatr Surg Int 1999;15:573-6.

18. Gabra HO, Jesudason EC, MCDowell HP, Pizer BL, Losty PD. Sacrococcygeal teratoma: A 25 year experience in a UK regional centre. J Pediatr Surg 2006;41:1513-6.

Source of Support: Nil, Conflict of Interest: None declared. 